Małgorzata Dziura

ORCID: https://orcid.org/0000-0001-7191-0894

Muzeum Narodowe Ziemi Przemyskiej w Przemyślu

\title{
Rola i znaczenie dźwięku dzwonów w kształtowaniu poczucia zadomowienia
}

\section{The role and significance of bells in the feeling of settlement}

\begin{abstract}
The feeling of settlement does not refer only to the house, that is, the walls creating a safe shelter, but also to the nearest surroundings where a person feels at home. In this text, these surroundings will be presented in the perspective of a soundscape - the sound of an environment where the ringing of bells is accompanied by a sense of homeliness and familiarity. Bells were, and still are, connected with the religious tradition, but they also express the relationship with the local space and evoke the feeling of settlement. The article aims to draw attention to the audial experience of the surroundings and to show the feeling of settlement through sounds that anchor people in a given space, but also awaken nostalgia and provide a safe asylum.
\end{abstract}

Key words: the feeling of settlement, community, bell, localism, sound, soundscape, nostalgia, sanctity, belonging.

Poczucie zadomowienia nie odnosi się wyłącznie do domu, czyli murów stanowiących bezpieczne schronienie, ale także do najbliższego otoczenia, gdzie człowiek czuje się u siebie. To otoczenie w niniejszym tekście zostanie przedstawione w perspektywie soundscape - brzmienia środowiska, w którym poczuciu domowości i swojskości towarzyszą dźwięki dzwonów. Dzwony były i nadal są związane z tradycją religijną, lecz także wyrażają związek z lokalną przestrzenią i wywołują poczucie zadomowienia. Artykuł ma na celu zwrócenie uwagi na audialne doświadczanie otoczenia i pokazanie poczucia zadomowienia poprzez dźwięki, które zakotwiczają człowieka w danej przestrzeni, zapewniają bezpieczny azyl oraz budzą nostalgię.

Słowa kluczowe: zadomowienie, wspólnota, dzwon, lokalność, dźwięk, krajobraz dźwiękowy, nostalgia, świętość, przynależność.

Odebrano / Received: 31.01.2019

Zaakceptowano / Accepted: 27.08.2019 


\section{Wprowadzenie}

Zadomowienie jest rodzajem zagospodarowania przestrzeni. $\mathrm{W}$ tej przestrzeni człowiek może się rozpoznać i czuć swojsko. Współczesność preferuje ruch i zmianę. Już klasyczne Baumanowskie typy osobowości - spacerowicz, włóczęga, turysta - podkreślają niespokojność, ruch, pęd, przemijanie, epizodyczność różnych sfer życia ${ }^{1}$. Niezależnie od głosów opowiadających się za kosmopolitycznością człowieka nadal istnieje potrzeba przynależności, poczucia tożsamości, zakorzenienia, bezpieczeństwa, wspólnoty i emocjonalnej łączności. Wszystkie te potrzeby są zaspokajane nie tylko przez przestrzeń domu, więzy rodzinne i przyjacielskie, ale także przez najbliższe otoczenie - przestrzeń lokalną z różnymi jej przedmiotami i dźwiękami, które pozwalają odczuć zadomowienie i swojskość. Problematyka związana z poczuciem stabilności, tożsamości i przynależnością do określonego miejsca na ziemi w świecie „płynnej nowoczesności” nurtuje wielu badaczy. Poszukują oni współczesnych wyjaśnień relacji człowiek - otoczenie. Pojawia się wiele pomysłów interpretujących wielorakie zależności ludzi od przestrzeni.

Funkcjonuje wiele kategorii pojęciowych wyjaśniających bycie człowieka w przestrzeni: wspólnotowość, lokalność, problematyka małej ojczyzny, ale także pojawia się idea zamieszkiwania, przynależności, tożsamości i społecznego zakotwiczenia. W artykule zwrócono uwagę na znaczenie środowiska dźwiękowego, które otacza człowieka, ale nie w pełnym wymiarze. Skoncentrowano się tylko na wybranych dźwiękach, które są związane z muzyką dzwonów. Proponowane ujęcie dźwięków sacrum łączy wiele koncepcji i kategorii pojęciowych, by wyjaśnić zadomowienie w określonym miejscu. W opracowaniu zespolono zadomowienie $\mathrm{z}$ tradycją dzwonów kościelnych i przestrzenią wiejską. Wyeksponowano fonosferę i wrażenia audialne jako element zakorzenienia, wspólnoty, poczucia zakotwiczenia i swojskości mieszkańców pogranicza nadsańskiego². Antropologiczno-socjologiczny namysł nad znaczeniem dzwonów i poczuciem zadomowienia uwzględnia także koncepcję „pejzażu dźwiękowego” (ang. soundscape), który zapoczątkował kanadyjski muzykolog Raymond Murray Schafer ${ }^{3}$. Zwraca uwagę na to, że dźwięk dzwonów, może konstruować tożsamość, szczególnie tożsamość małych społeczności wiejskich, ale także dawać poczucie przynależności do określonego kręgu kulturowego. Niniejszy tekst jest oparty na materiale empirycznym zebranym podczas badań terenowych zrealizowanych w ramach projektu pt. Dzwony w pejzażu pogranicza nadsańskiego ${ }^{4}$. Badania realizowane były na ziemi przemyskiej, która słynie

1 Bauman 2011, s. 435-458.

2 Pogranicze nadsańskie to geograficznie część Pogórza Przemyskiego i Pogórza Dynowskiego, województwo podkarpackie.

3 Szerzej zob.: Schafer 1994.

4 Badania pod tytułem Dzwony w pejzażu pogranicza nadsańskiego były realizowane w ramach programu Ministerstwa Kultury i Dziedzictwa Narodowego na 2017 rok: Kultura ludowa i tradycyjna. Celem projektu była przede wszystkim dokumentacja i archiwizacja materialnego i niematerialnego znaczenia dzwonów występujących na badanym terenie od Krasiczyna do Mrzygłodu, w gminach Krasiczyn, 
z ludwisarstwa, a dzwony przez wieki towarzyszyły miejscowej ludności, pełniąc różne role, o których dziś się zapomina.

Dzwony na tym terenie są spuścizną kulturową zarówno ludności polskiej, jak i ukraińskiej. Historyczne wydarzenia związane z II wojną światową i powojennymi przesiedleniami ludności w ramach akcji „Wisła” spowodowały wiele negatywnych następstw. Niektóre świątynie greckokatolickie uległy zniszczeniu, ucierpiały także dzwonnice i wiszące w nich dzwony. W świadomości starszych mieszkańców tego terenu tkwią wspomnienia związane z lokalnymi dzwonami rzymsko- i greckokatolickimi i te wspomnienia warto ocalić od zapomnienia. Analiza materiału badawczego pozwala zwrócić uwagę na znaczenie dzwonu jako elementu wpływającego na przestrzeń zamieszkania oraz na wartości, jakie są z nim związane. Obecnie często mówi się o zmierzchu dzwonów, jednak nadal ilekroć rozbrzmiewa ich dźwięk to przypomina o religijnych wartościach lub ważnych wydarzeniach. Zebrane wywiady dotyczą przede wszystkim pamięci o tym, jak kiedyś funkcjonowały dzwony i co do dnia dzisiejszego pozostało $\mathrm{z}$ ich wielorakich funkcji. Wypowiedzi rozmówców, starszych mieszkańców tego terenu, oddają doświadczenia związane z tym kościelnym instrumentem.

\section{Zadomowione doświadczenie foniczne}

Skoncentrowanie uwagi na wymiarze audialnym wyznacza ciekawą perspektywę refleksji nad poczuciem zadomowienia i zakorzenienia, uzupełnia wizualny aspekt postrzegania przestrzeni. Problematyka audiosfery - dźwiękowego środowiska człowieka jest rozpatrywana w ramach sound studies i uwzględnia różne dźwięki oddziałujące na człowieka. Dźwięki zdaniem Roberta Losiaka i Renaty Tańczuk można potraktować

jako aktywnych nie-ludzkich aktorów, będących pełnoprawnymi elementami zbiorowości, którzy zawiązują relacje między ludźmi i różnymi pozaludzkimi czynnikami, takimi jak rzeczy, rośliny, zwierzęta i przestrzenie 5 .

Wszystkie dźwięki, szumy, odgłosy tworzą audiosferę danego miejsca i przyczyniają się do kształtowania pejzażu dźwiękowego. Raymond Murray Schafer w latach 60. XX wieku zaproponował koncepcję ekologii dźwiękowej i pejzażu dźwiękowego. Schafer ujmuje pejzaż dźwiękowy jako twór społeczny, który jest kształtowany przez ludzi i jednocześnie oddziałuje na nich. Jest to fragment środowiska z wszystkimi dźwiękami. Renata Tańczuk, analizując pejzaż dźwiękowy, przybliża samą koncepcję, jak i jej

\footnotetext{
Krzywcza, Dubiecko, Dynów, Nozdrzec, Dydnia i Sanok (33 miejscowości). Badania były przeprowadzone metodą wywiadu swobodnego z mieszkańcami i proboszczami lokalnych parafii. Przeprowadzono 65 wywiadów. Rozmówcami byli starsi ludzie, którzy w trakcie przeprowadzania wywiadu przypominali sobie różne opowieści o dzwonach. Opisując dzwony, rozmówcy najczęściej na początku mówili, że niewiele o nich wiedzą, ale w trakcie trwania rozmowy przypominali sobie coraz więcej faktów.

5 Losiak, Tańczuk 2015, s. 193.
} 
praktyczne zastosowanie badawcze. Zwraca uwagę na zanieczyszczone hałasem środowisko dźwiękowe, niewrażliwość naszej kultury na percepcję dźwięku oraz akcentowanie w niej postrzegania wzrokowego Zauważa także, że koncepcja pejzażu dźwiękowego ułatwia rozpatrywanie doświadczania konkretnej przestrzeni' ${ }^{6}$. Badacze pejzażu dźwiękowego szukają dźwięków, które są ważne dla ludzi, mają symboliczne znaczenie i określają specyfikę miejsca.

Pejzaż dźwiękowy tworzy atmosferę miast i wsi. Dźwięki lokalne, brzmienie środowiska są nie tylko zorganizowane i przynależne do danej przestrzeni, ale też indywidualnie odbierane przez człowieka. Perspektywa wartościowania dźwięków otoczenia przyczynia się do odbioru określonego miejsca. Dla niektórych ludzi wielkomiejski gwar, hałas jest tym, z czym się identyfikują, dla innych cisza i spokój jest pożądaną wartością. Różne zjawiska akustyczne, nie tylko te akceptowane, ale nawet hałas może łączyć ludzi w społeczności akustyczne.

Krajobraz dźwiękowy jest sumą wszystkiego, co dzieje się w przestrzeni akustycznej, a odbiór tych dźwięków jest indywidualnie odbierany przez człowieka. Badania na pograniczu nadsańskim potwierdzają tezę o specyfice odbioru dźwięków kościelnych dzwonów:

(...) jak coś jest od zawsze, to się na to nie zwraca uwagi [M., ur. 1950 r., Brylińce, gm. Krasiczyn $]^{7}$.

Stychać ich bicie i ten dżwięk jest taki naturalny, że nie zwraca się na niego uwagi. Codziennie $d z$ wony dzwoniq. Jak cośtrwa od lat, to jest się na to obojętnym [K., ur. 1959 r., Tarnawka, gm. Dubiecko].

Mieszkańcy pogranicza nadsańskiego na co dzień zazwyczaj nie słyszą i nie wsłuchują się w otaczające dźwięki, gdyż są one oczywistym elementem przestrzeni. Bicie dzwonów jest mocno przyswojone i utrwalone przez rozmówców, staje się nieistotne i nie skłania do refleksji. Zainteresowanie nim ujawnia się dopiero w sytuacji wywiadu. Środowisko dźwiękowe bardzo często jest niedostrzegane do chwili wyobcowania z niego lub konieczności refleksji nad nim. Robert Losiak podkreśla, że:

Poczucie zadomowienia w określonym środowisku fonicznym często pozostaje dla nas samych ukryte; ujawnia się natomiast w momencie, w którym dochodzi do konfrontacji z obcym, nieznanym wcześniej pejzażem dźwiękowym ${ }^{8}$.

6 Tańczuk 2015, s. 10-19.

7 Wszystkie zapisy fragmentów wywiadów w niniejszym tekście będą mieć oryginalną formę wypowiedzi, także gwarową. Wywiady znajdują się w Archiwum Etnograficznym Muzeum Narodowym Ziemi Przemyskiej w Przemyślu. M - mężczyzna, K - kobieta, ur. - urodzony/a.

8 Losiak 2010, s. 226. 
Zadomowienie w perspektywie soundscape jest organizacją dźwięków otoczenia, ale także umiejętnością słuchania tego, co jest w koło i indywidualnego odbioru dźwięków. Foniczny odbiór rzeczywistości to uchwycenie nastrojów i wrażeń. Zadomowienie w sensie audialnym określają dźwięki stale obecne, choć nie muszą być stale słyszane. Do takich dźwięków należy bicie dzwonu. Respondenci na pytania o rolę i znaczenie dzwonów najczęściej mówili o kościelnym instrumencie, dopiero, gdy pojawiały się pytania o lokalne dzwony zwracali uwagę na ich dźwięk, który jest obecny w miejscu zamieszkania. W doświadczeniu badanych obecność muzyki dzwonów tworzy foniczny wymiar zamieszkiwania.

Podobnie jak uporządkowana według własnej koncepcji przestrzeń daje poczucie zadomowienia, tak i otoczenie dźwiękowe pozwala na poczucie swojskości. Dźwięk odgrywa bardzo istotną rolę w kreowaniu naszego dobrego samopoczucia w danym miejscu czy przestrzeni. Dom/mieszkanie stanowi centrum przestrzeni, w której można stworzyć najbardziej przyjazne warunki foniczne. Sąsiedztwo można potraktować jako rozszerzoną przestrzeń domowego centrum. Otoczenie dźwiękowe może tworzyć idealne miejsce, w którym człowiek czuje się dobrze, ale też może być męczące i utrudniać zadomowienie. Co więcej niepożądane zjawiska akustyczne, na przykład hałas, mogą wyzwalać złe emocje w stosunku do określonego miejsca i uniemożliwiać zadomowienie. Pożądanym zjawiskiem akustycznym związanym z zadomowieniem jest cisza.

\section{Przestrzeń zadomowienia}

Zadomowienie to pojęcie, które przysparza wielu problemów definicyjnych. Wynikają one z faktu, że wspólnym mianem zadomowienia określa się zjawiska związane z różnymi przestrzeniami. Przestrzeń zadomowienia nie odnosi się wyłącznie do domu, czyli murów stanowiących bezpieczne schronienie, gdzie człowiek żyje, przebywa, czy jedynie nocuje, ale chodzi o mniejszy lub większy obszar, w którym jednostki czują się u siebie, takie jak podwórka, osiedla, wsie, miasta itp. Przestrzeń tę człowiek konstruuje przez swoją aktywność, ale też bezpośrednio jej doświadcza. Te trwałe połączenia między jednostką a przedmiotami i zjawiskami otoczenia przyczyniają się do poczucia swojskości, bezpieczeństwa i zakorzenienia.

Zadomowienie jest zatem równoznaczne $\mathrm{z}$ uznaniem przestrzeni za własną, ale oznacza także harmonijną relację człowieka $z$ najbliższym otoczeniem. Obejmuje obszar, który można określić jako „swój”. Człowiek, czyniąc miejsce zadomowionym, staje się jego gospodarzem, poddaje go wartościowaniu i ma do niego emocjonalny stosunek.

Magdalena Łukasiuk proponuje postrzeganie zadomowienia $z$ wielu perspektyw. Dostrzega związki z pojęciem komfortu, ciała, przywołuje poczucie mojości Grażyny Woronieckiej oraz perspektywę praktyk społecznych. Zwraca uwagę na inne kategorie przestrzenne, takie jak sąsiedztwo, mała ojczyzna czy wspólnota, które pozwalają lepiej zrozumieć zadomowienie. Podkreśla, że zadomowienie jawi się jako relacja człowieka 
z przestrzenią ${ }^{9}$ Ważnym pojęciem ujmującym związki ludzi z przestrzenią, istotnym ze względu na opis jej zadomowienia, jest lokalność.

Zdaniem Andrzeja Majera lokalność jest

terminem nieodłącznym od miejsca, terytorium czy regionu. Jest także pojęciem normatywnym i wartościującym, kojarzącym się z granicami, zamkniętością, ograniczonością, do pewnego stopnia także zaściankowością lub wręcz zacofaniem. Jednocześnie nowoczesne odmiany lokalności wyrastające z idei komunitariańskich odwołują się do wspólnotowych źródeł życia społecznego, rozszerzając je, akcentując podmiotowość lokalnych społeczności i postulując włączanie obywateli do samodzielnego rozwiązywania problemów ${ }^{10}$.

Lokalność kojarzona jest z umiejscowieniem w przestrzeni i kultywowaniem stałych wartości, ale jednocześnie $\mathrm{z}$ aktywnym kształtowaniem swojego środowiska życia. Lokalny styl życia łączy się z przywiązaniem do określonych miejsc prywatnych i publicznych, identyfikacją z wybranym fragmentem przestrzeni, współmieszkańcami i całą sferą foniczną. Lokalność związana jest z kategorią wspólnoty.

Mimo że obecnie mówi się wiele o tym, że termin „wspólnota” staje się mgławicowy, a więzi terytorialne zanikają na rzecz powiązań globalnych, to nadal „wielu autorów diagnozuje istnienie wspólnot, choćby trwających w stanie latentnym i aktywizujących się pod wpływem szczególnych, zewnętrznych okoliczności społecznych, ekonomicznych, politycznych lub przyrodniczych"11. Zebrane w trakcie badań wywiady pozwalają dostrzec rolę dźwięków dzwonów w tworzeniu wspólnoty. Jest to wspólnota postrzegana przez pryzmat identyfikacji i tożsamości. Wymiar bezpośrednich styczności i wspólnego terytorium nie odgrywa tutaj istotnej roli. Różne ważne wydarzenia, najczęściej tragiczne, jednoczą ludzi i przywracają więzi społeczne. Dźwiękiem towarzyszącym tym wydarzeniom jest bardzo często bicie dzwonów, o którym Aleksander Borawski pisał: „W uroczystościach odgłos dzwonu potęguje radość publiczną, a nieszczę́liwym zdarzeniom więcej okropności nadaje"12. Wspólnotowość ujawnia się w chwilach doniosłych i ważnych, których znaczenie podkreśla muzyka dzwonów. Dzwony (w tym Dzwon Zygmunta w Krakowie czy amerykańska „Wieża głosów” $\left.{ }^{13}\right)$, które biły z okazji ważnych rocznic, na przykład stulecia odzyskania niepodległości przez Polskę, smutnych lub tragicznych wydarzeń, takich jak śmierć Jana Pawła II, upamiętnienie ofiary strzelaniny w Strasburgu ${ }^{14}$,

9 Eukasiuk 2018, s. 6-11.

${ }^{10}$ Majer 2011, s. 29.

${ }^{11}$ Łukasiuk 2018, s. 10.

${ }^{12}$ Borawski 1921, s. 55.

13 „Wieża głosów” to pomnik składający się z 40 dzwonów upamiętniających ofiary lotu 93 z 11 września 2001, z dnia zamachów na World Trade Centre i Pentagon.

${ }^{14}$ W 2018 roku w Strasburgu zabiły dzwony, które upamiętniły ofiary ataku terrorystycznego dokonanego podczas jarmarku bożonarodzeniowego. 
łączą ludzi. W tym kontekście warto przytoczyć pogląd Roberta Losiaka, że współcześnie „lokalne” dźwięki dzwonów coraz bardziej tracą znacznie punktów fonicznej orientacji i koncentracji, skupiających lokalne wspólnoty. Jednocześnie jednak za sprawą nowoczesnych technik transmisji dźwięku pojawia się możliwość tworzenia innego rodzaju wspólnot fonicznych - państwowych czy narodowych, a być może także ponadnarodowych ${ }^{15} . Z$ analizy wywiadów wynika, że element fonosfery, jakim jest bicie dzwonów przyczynia się do poczucia wspólnoty, a w szerszym wymiarze funkcjonuje niejako równolegle z lokalną wspólnotą. We wspomnieniach mieszkańców pogranicza nadsańskiego miejscowe dzwony w sytuacjach ważnych dają poczuci jedności. Jeden z respondentów tak mówit:

Pamientom, miotem szósty rok, jak Pitsudski umart to dzwonili dtugo, dtugo dzwonili. Teroz, jak umart nasz papież, święty Jan Pawet II. Ludzi to dzwonienie tak jednoczyto [M., ur. 1929 r., Bachórzec, gm. Dubiecko].

Mieszkanka Krzywczy też kojarzy bicie w dzwony z ważnymi dla narodu wydarzeniami: Jak jest taka okazja wielka, jakieś wydarzenie wielkie to też się dzwoni, jak zmart Jan Pawet II to dzwonili, pewnie, że dzwonili [K., ur. 1950 r., Krzywcza]. Raymond Murray Schafer uważa, że „dzwon kościelny ześrodkowuje: przyciąga i jednoczy społeczność”16. Podobnie Alain Corbin podkreśla, że dźwięk dzwonów kościelnych i ich przemiany, które dokonały się na francuskiej wsi w XIX wieku przyczyniły się do zakorzenienia ludzi w lokalnej przestrzeni i wyznaczyły granice takiejż wspólnoty ${ }^{17}$. Dźwięki związane z religią odgrywają szczególną rolę we wszystkich kulturach. Charakterystycznym dźwiękiem wspólnotowym w krajach muzułmańskich jest śpiew muezina, a w chrześcijaństwie kościelny dzwon. To dźwięk tego instrumentu przez wieki towarzyszył i nadal towarzyszy wspólnocie chrześcijańskiej, ale też zyskał inne znaczenia.

Wspólnotowość na terenie pogranicza nadsańskiego nie jest typem idealnym pojęcia wprowadzonego przez Ferdinanda Tönniesa ${ }^{18}$, ale dzwony współtworzą homogeniczność mieszkańców pod względem wartości i norm. Zróżnicowanie stylów życia, profesji, przestrzeni przebywania i doświadczania nie zmienia sposobu postrzegania dzwonów jako ważnej wartości. Mieszkańcy nadal chcą słyszeć bicie dzwonów. Jeden $\mathrm{z}$ respondentów tak mówit:

$U$ nas to $d z w o n$ nie $d z w o n i c z e s t o$, ale raczej bez $d z w o n u$ to by nie byto. Jest takie przywiazanie do tego dzwonu. Jakby coś się stato z tym dzwonem, to coś by musiato być, albo remont albo nowy. Nie, bez dzwonu to nie [M., ur.1950 r., Brylińce, gm. Krasiczyn].

\footnotetext{
${ }^{15}$ Losiak 2012, s. 151.

${ }^{16}$ Schafer 1982, s. 304.

${ }^{17}$ Corbin 1998.

18 Tönnies 2008.
} 
Ze szczególną sympatią rozmówca odnosi się do dźwięków dzwonów. Ten dźwięk buduje poczucie stabilności w przestrzeni zamieszkania.

We wspomnieniach ludzi tego terenu żywa jest pamięć o „walce w obronie” dźwięku sacrum:

Jak dzwony zadzwonity to wszystkie ludzie byty takie zadowolone, bo dzwony bity tak radośnie. Niestety szybko przestaty bić i to na dtugo, bo ubowcy nie pozwolili $d z w o n i c ́(. .$.$) . Dzwony byty$ dalej zaplombowane. Wybrano nowa rade parafialna i ona jeździta do różnych wtadz, powiatu, wojerwództwa, żeby uruchomić dzwony [M., ur. 1938 r., Dylągowa, gm. Dynów].

Przywrócenie głosu rozkołysanym spiżom mobilizowało ludzi do działania i trudu. Wielką ofiarnością, a nawet bohaterstwem wykazywali się mieszkańcy, którzy ukrywali dzwony podczas II wojny światowej. Małgorzata Dziura pisze:

Dla ludzi i dzwonów szczególnie niebezpieczne były czasy wojen. Dzwony były rekwirowane i przetapiane na armaty. Miejscowa ludność strzegła dzwonów i gdy groziło im niebezpieczeństwo, ukrywała je. Ziemie pogranicza nadsańskiego to kącik Polski na styku etnicznym polsko-ukraińskim. W czasie II wojny światowej San wyznaczał granice między Niemcami a Związkiem Radzieckim i jeżeli spojrzymy na krajobraz pogranicza nadsańskiego z tych czasów, to jawi się ono w ogniu i dymie, w ruinach i zgliszczach, w przemarszach wojsk, dramatach ludzkich ${ }^{19}$.

Opowieść o ukrytych dzwonach znają mieszkańcy Bachórca: W nocy, ciężko byto, trzy dzwony schowali. Do stawu wrzucili, tam, gdzie stara dzwonnica jest [M., ur. 1929 r., Bachórzec, gm. Dubiecko]. Na tym terenie ukryto także wiele cerkiewnych dzwonów, które do dzisiaj nie zostały odnalezione, na przykład w Piątkowej. O tym dzwonie funkcjonuje taka informacja:

To, co ja styszat od starszych ludzi, których już ni ma, poumierali, że dzwon ma być jeden zakopany, tam gdzie leśniczórwka jest w Piatkowej, ale gdzie, w którym miejscu, to nie wiadomo [M., ur. 1947 r., Piątkowa, gm. Dubiecko].

W wypowiedziach rozmówców na temat dzwonów są wyraźne wskazania na lokalność i wspólnotowość tego instrumentu. W doświadczeniach ludzi dzwony zespalają mieszkańców, a ich dźwięk jest ważny zwłaszcza w doniosłych wydarzeniach.

${ }^{19}$ Dziura 2017, s. 19. 


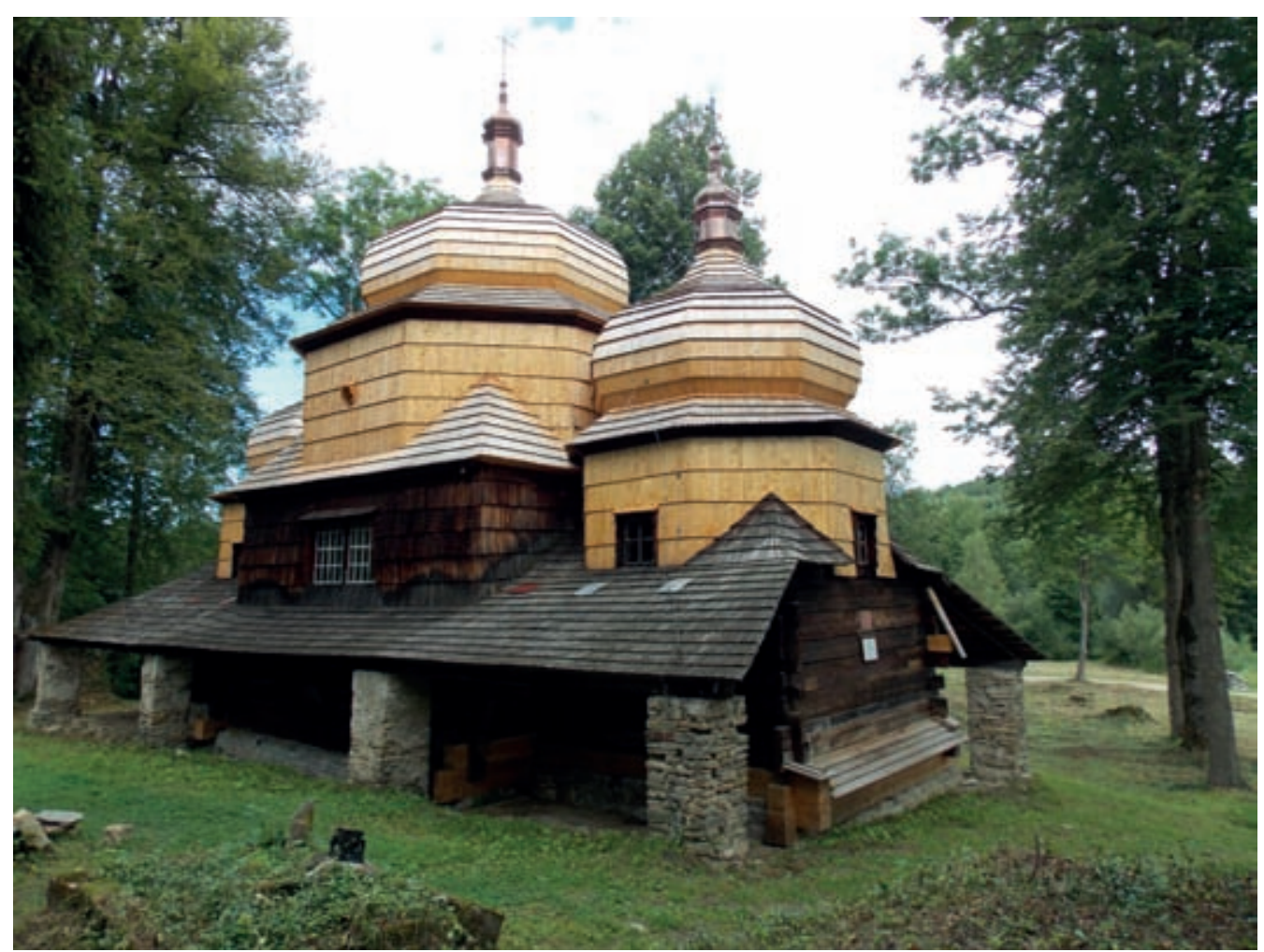

Cerkiew greckokatolicka pw. św. Dymitra, opuszczona w 1947 r, według przekazów na jej terenie ukryty jest dzwon, Piątkowa, gm. Dubiecko, fot. M. Dziura 2017

\section{Dzwon - kotwica}

Dzwony są to specyficzne instrumenty muzyczne należące do grupy idiofonów, które posiadają zdolność przenoszenia dźwięku na duże odległości. Muzyka dzwonów od stuleci zwoływała wiernych do kościołów na modlitwę i nabożeństwa, ale też symbolizowała głos samego Boga, była środkiem apotropeiczno-magicznym, sygnałem ostrzegawczym i informacyjnym. Dzwony ze względu na znaczenie religijne były związane z miejscem i czasem sacrum, ale też z codziennym życiem. Historia dzwonów liczy sobie około 5 tysięcy lat. Za ich ojczyznę uznaje się kontynent azjatycki, skąd rozprzestrzeniły się na cały świat. Wojciech Komorowski pisał: „Dzwony znane były w większości kultur starożytnych: w Egipcie, Babilonii, Chinach, Indiach, Grecji czy Rzymie, używano ich od dawna w wielu rejonach Afryki i Ameryki” ${ }^{20}$. Swą popularność dzwony jednak zawdzięczają upowszechnianiu się chrześcijaństwa w Europie i przyjęciu ich przez kościół do powszechnego użytku.

\footnotetext{
${ }^{20}$ Komorowski 1988 , s. 8.
} 
Współcześnie zapomina się o bogactwie znaczeniowym i różnych funkcjach dzwonu, ale jego kulturowa wartość jest ciągle aktualna. Dzwony należą do kotwic kulturowych, ponieważ mają silne tradycje, a ich dźwięk daje poczucie „bycia u siebie” i zakorzenienia w kulturze chrześcijańskiej. Karolina Ciechorska-Kulesza powołując się na koncepcję Aleksandry Grzymały-Kozłowskiej pisze:

Jednym z głównych wyzwań współczesnego człowieka jest znalezienie kotwic w zmiennej rzeczywistości, która prowadzi do ciągłego budowania przez jednostki tożsamości, czy jej poszukiwania ${ }^{21}$.

Metafora kotwicy w sposób obrazowy może wyjaśniać istnienie stabilnych punktów w zmiennej rzeczywistości, które zapewniają poczucie bezpieczeństwa i pewności. Kotwice dają ustabilizowanie i połączenie $z$ innymi elementami. Sama autorka koncepcji zakotwiczenia uważa, że kotwice mogą działać na zasadzie bodziec-reakcja i stwierdza: „kotwica jest dowolną reprezentacją (takim bodźcem może być na przykład dźwięk, obraz lub zapach) wyzwalającą inną reprezentację (taką jak wspomnienie miejsca czy przeżycia ${ }^{22}$. Odwoływanie się do stabilnych punktów, takich jak doświadczenia, przekonania, przeżycia czy wartości jednostki pozwala przywrócić lub utrzymać jej zakorzenienie, zadomowienie, tożsamość i stałość. Aleksandra Grzymała-Kozłowska uważa, że „wykorzystywane przez człowieka kotwice pozwalają mu zlokalizować swoje „miejsce w świecie”, upostaciowić swoje poczucie istnienia oraz dają jednostce podstawę psychologicznego i społecznego funkcjonowania"²3. Taką kotwicą może być dźwięk dzwonu stanowiący stały punkt odniesienia, gdyż jest utrwalonym symbolem kulturowym, ale także codzienną praktyką. Bicie dzwonów jest „zjawiskiem długiego trwania”, powtarzalną czynnością, a strategia zakotwiczenia, zadomowienia i oswajania polega na powtarzaniu określonych działań, by poczuć się „u siebie” i znaleźć oparcie w swoim życiu. $\mathrm{Na}$ terenie pogranicza nadsańskiego dzwony „zakotwiczenia” odzywają się regularnie zwykle pół godziny przed rozpoczęciem mszy świętej i w momentach powszechnie znanych mieszkańcom. Te wypowiedzi potwierdzają znajomość czasu dzwonienia i jego regularności:

Teraz jeden dzwon dzwoni na Aniot Pański w potudnie, rano i wieczorem przed msza. W nie$d z i e l e$ wszystkie dzwony przed msza dzwonia. Jest taki zwyczaj, ̇̇e dzwoni się, jak ktoś umrze. Trzeba iść do księdza i zgtosic, wtedy ksiadz wtacza dzwony, bo sq automatyczne [M., ur. 1936 r., Grabówka, gm. Dydnia].

${ }^{21}$ Ciechorska-Kulesza 2018, s. 91.

${ }^{22}$ Grzymała-Kozłowska 2013, s. 51.

${ }^{23}$ Grzymała-Kozłowska, 2013, s. 53-54. 
Dzwony dajo ludziom znak, że będzie msza, taka informacja, że trza się zbierać do kościota. Tak dawni to ludzie stuchali dzwonórw. Jak w potudnie dzwonili to schodzili z pola na odpoczynek [K., ur. 1935 r. Nozdrzec]. Dzwonia trzy razy w ciagu dnia. Rano o 6.00, potem o $12.00 \mathrm{i}$ wieczorem (...). Jak sa jakieś uroczystości i święta to też dzwony dzwonia. Daleko stychać ich gtos [K., ur. 1949 r., Dynów].

Dzwony dają poczucie ciągłości i trwania, jak mówili czasami respondenci: tak byto za naszych dziadów i pradziadów. Koncepcja zakotwiczenia zakłada także pewną elastyczność, to znaczy modyfikowanie i zmianę. Doświadczanie dźwięków dzwonów może się zmieniać i przekształcać, jednak ich istota i znaczenie pozostają niezmienne.

Zakotwiczenie wiąże człowieka z określonym miejscem na ziemi i tworzy poczucie przynależności. Przynależność to „relacja między jednostką a jakąś całością oparta na „byciu częścią”, podporządkowaniu i szczególnej dyspozycji psychicznej wyrażającej stan lub pragnienie "bycia włączonym”" ${ }^{2}$. Z tego włączenia wynika więź z miejscem, przestrzenią i ludźmi, a także wytyczenie zakresu działalności i aktywności. Przynależność do określonej przestrzeni można nazwać współzamieszkiwaniem. Współzamieszkiwanie polega na braniu odpowiedzialności za miejsce i jest związane $\mathrm{z}$ kształtowaniem poczucia świadomości „my” we wspólnej przestrzeni. Dźwięk dzwonów jest jednym z elementów dającym poczucie przynależności i to nie tylko do lokalnej parafii, ale także do wspólnoty narodowej i chrześcijańskiej. $Z$ dźwiękiem wiąże się aktywność, która potwierdza zakotwiczenie. Ludzie w wielu miejscach podejmowali działania związane z dzwonami, ponieważ czuli, że jest to coś stałego i niezmiennego, na przykład jedna z mieszkanek Dynowa mówiła:

Ludzie oddawali jakieśszlachetne metale na dzwony. Co tam, kto w domu miat z wartościowych metali to oddawat. Mama oddata taki mosiężny dzbanek. Dla wszystkich ważne byto, żeby zakupić dzwony. Byta taka mobilizacja wśród mieszkańców [K., ur. 1949 r., Dynów] ${ }^{25}$.

Nie tylko w dawnych czasach działano wspólnie na rzecz zakupu lub odzyskania dzwonów stanowiących lokalną wartość. Nadal społeczna aktywność pojawia się, gdy trzeba przywrócić świetność dzwonom lub ufundować nowe. Większość mieszkańców Tarnawki (gm. Dubiecko) ma swój pieniężny udział w remoncie dzwonów. Z kolei w Warze (gm. Nozdrzec) wyremontowane dzwony czekają na przywrócenie świetności dawnej cerkwi.

\footnotetext{
${ }^{24}$ Łukasiuk 2018, s. 11.

${ }^{25}$ Dodać należ, że w miejsce utraconych w czasie II wojny światowej dzwonów mieszkańcy Dynowa i okolic ufundowali w 1958 roku trzy nowe dzwony: Królowa Polski Maryja, św. Wawrzyniec i św. Antoni. Na powrót dzwonów na wieżę mieszkańcy czekali i podejmowali różne działania, by dzwony zostały odlane, np. zbiórkę metali szlachetnych.
} 


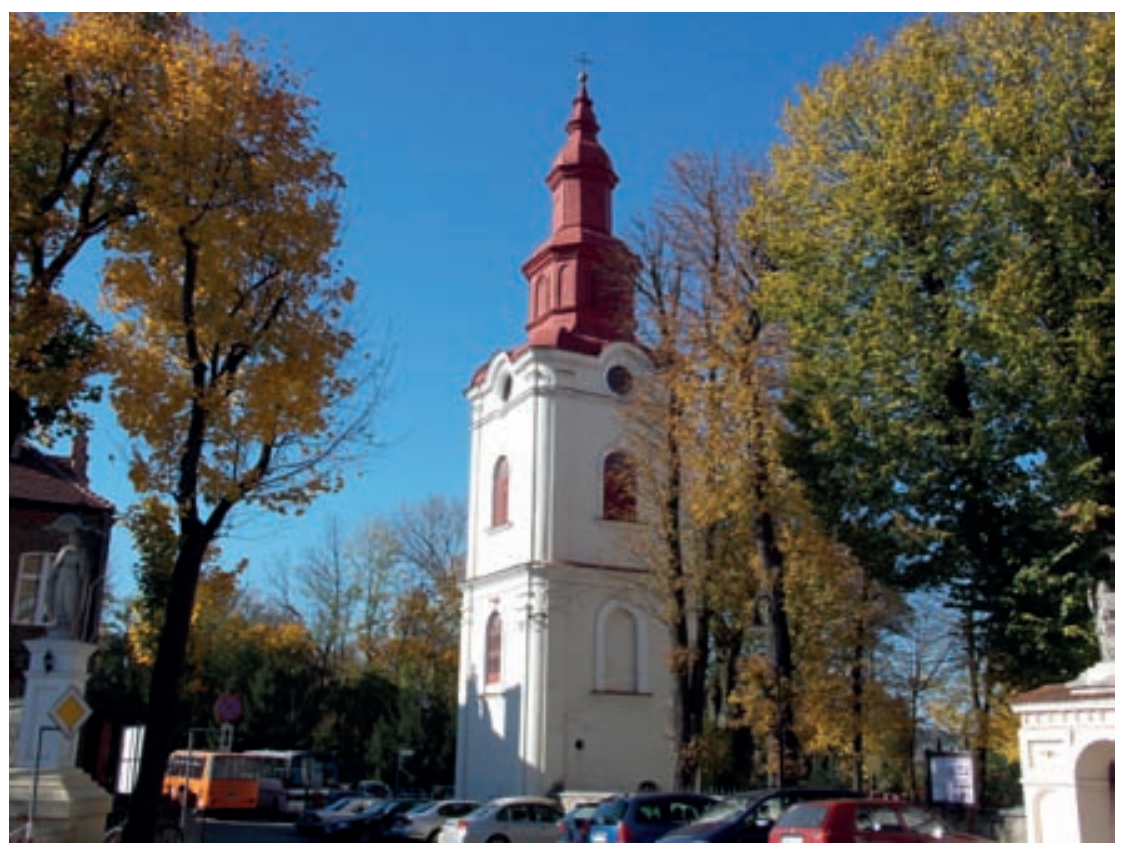

Dzwonnica datowana na XVIII w., Dynów, fot. P. Karnas 2017

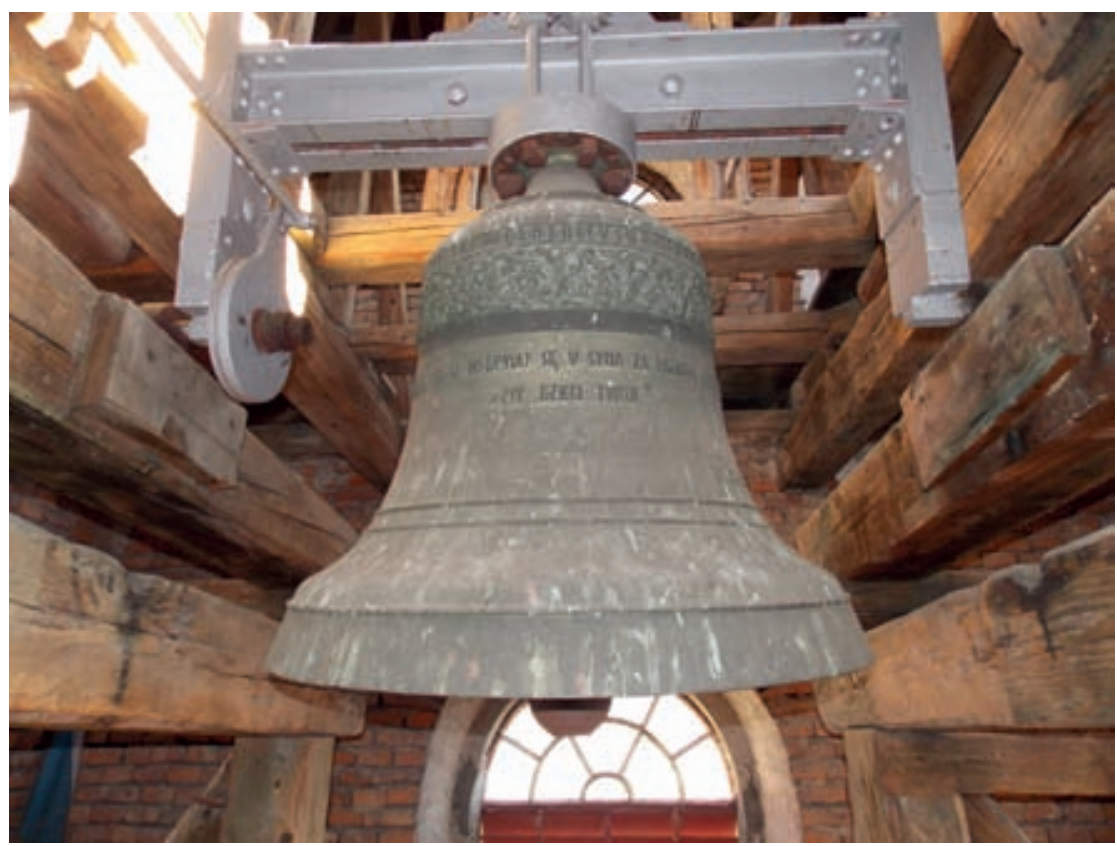

Dzwon z sentencją: KRÓLOWO POLSKI WSTAWIAJ SIĘ U SYNA ZA PARAFIA DYNOWSKA MY DZIECI TWOJE, Dynów, fot. P. Karnas 2017 


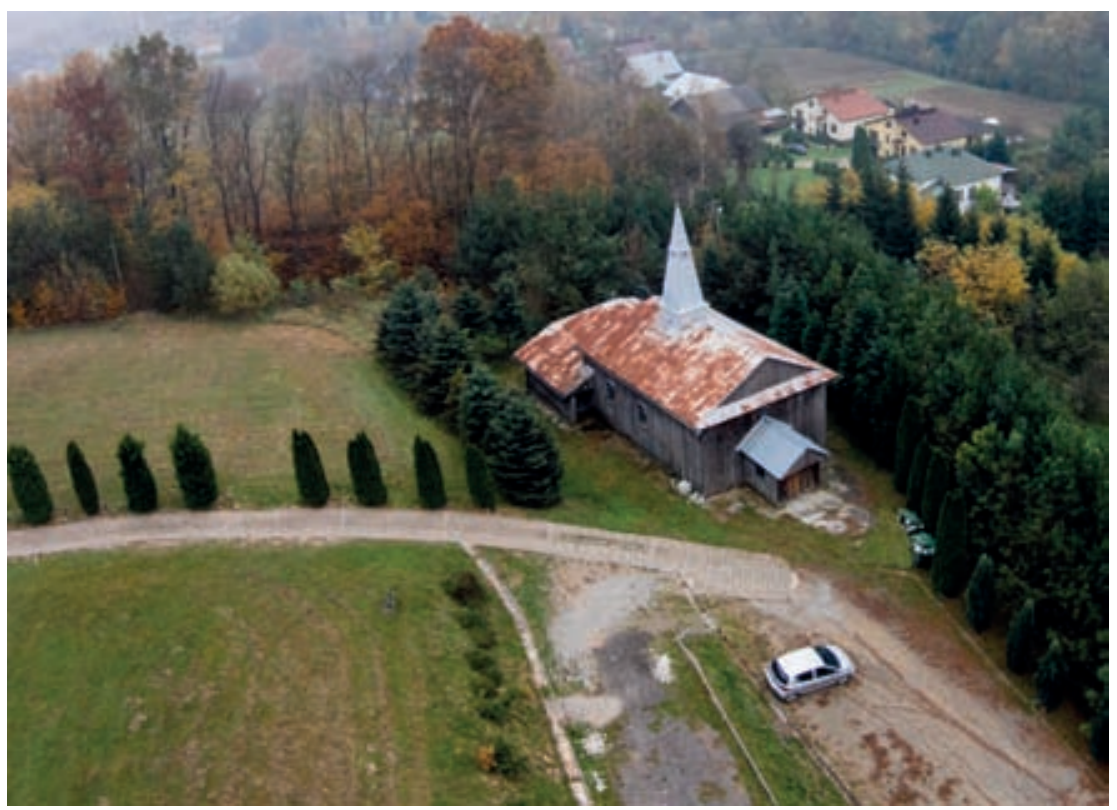

Cerkiew greckokatolicka p.w. Podwyższenia Krzyża Świętego, w latach 1946-1985 kościół filialny parafii w Nozdrzcu, obecnie nieużytkowana, Wara, gm. Nozdrzec, fot. P. Husarz 2017

\section{Retrotopia dzwonowa}

Przy omawianiu zadomowionych dźwięków dzwonów ważne zagadnienie stanowi nostalgia. Wielu ludzi odczuwa nostalgię za odchodzącym światem i patrzy na współczesność przez pryzmat przeszłości. Zygmunt Bauman, cytując Svetlanę Boym, podkreśla, że retrotopia stała się epidemią nostalgii za dawnymi czasami, tęsknotą za wspólnotą o zbiorowej pamięci, a wyobrażona przeszłość ma zdolność kreowania współczesności ${ }^{26}$. Nieznane i przyszłe bardzo często wywołuje strach, dlatego nostalgia za tym, co pewne i znane przyczynia się do poczucia bezpieczeństwa i stałości. Nostalgia przywraca utracone układy odniesienia i zwiększa poczucie przynależności społecznej oraz umieszcza człowieka w strefie komfortu.

Dzwony w nostalgicznym oglądzie świata wywołują skojarzenia z przeszłością, mimo że są stale obecne. Dawniej pełniły wiele funkcji i były wykorzystywane w wielu sferach życia codziennego. Wielorakie znaczenie dzwonów oddają słowa Tadeusza Szydłowskiego, który przed wieloma laty pisał:

Splotły się dźwięki dzwonów z porywami i tęsknotami dusz naszych; przywykliśmy słyszeć w nich głosy wesela i smutku. Przejmuje nas ich jęk ponury w chwilach żałoby, radują

\footnotetext{
${ }^{26}$ Bauman 2018, s. 9-12.
} 
huczne tony w dni uroczyste. Rosną serca, gdy w chwilach narodowych zwycięstw zabrzmi potężny hymn Te Duem laudamus, którego pierwsze słowa na dzwonach często się pojawiają. Wszelkie momenty w życiu religijnym i obrzędy społeczne, znajdują w dźwięku dzwonów swój wyraz ${ }^{27}$.

Te słowa kierują uwagę w stronę utrwalonych znaczeń. W świadomości mieszkańców pogranicza nadsańskiego dzwon funkcjonuje jako przedmiot związany z kościołem, ale także jako dźwięk towarzyszący codziennemu życiu. Wypowiedź respondentki z Dynowa potwierdza utrwalone w świadomości skojarzenia z dzwonem:

Dzwon to instrument muzyczny, ale ścisle zwiqzany z kościotem. Jak stychać dzwony to jest mito, swojsko $i$ wiadomo, że to z kościota gtos. U nas dzwony bija bardzo tadnie. Maja taki czysty, potężny dźwięk, sq dobrze zestrojone [K., ur. 1949 r., Dynów].

Dźwięk dzwonów wpisał się szczególnie w krajobraz foniczny wsi, tworząc swoistą atmosferę. Klimat dawnej wiejskości przywołują słowa Tadeusza Szydłowskiego:

Czyż można wyobrazić sobie wieś i poezję wieczoru bez zwyczaju, że na Anioł Pański biją dzwony! A czasem zmącą spokój tony urywane, gwałtowne, groźne, zwiastujące pożar lub jakieś nieszczęście ${ }^{28}$.

Ten krajobraz tradycyjnej wsi ze swoistymi dźwiękami, takimi jak rżenie koni, pianie kogutów, brzęk kos w czasie żniw, bicie kościelnych dzwonów itp. nadal funkcjonuje i jest mocno utrwalony w świadomości. Bardzo często dźwięki te już nie funkcjonują, jednak nadal są obecne w nostalgicznych wspomnieniach starszego pokolenia. Za ciszą i spokojem oraz przyjaznymi dźwiękami wiele osób tęskni.

Przekazywanie legend i opowiadań o dzwonach jest ważnym świadectwem znaczenia dzwonów dla mieszkańców nadsańskich wsi, ale także lekcją historii lokalnej, na przykład o przestrzelonym dzwonie w Dobrej ${ }^{29}$. Takie opowiadania to nie świadczą o nostalgii za wojennymi czasami, ale za heroizmem życia. Ukrywanie dzwonów w trudnych czasach wyzwalało w ludziach odwagę, pomysłowość, chęć działania i to pozostaje w pamięci mieszkańców. Przejawem nostalgii za dawnymi czasami jest chęć upamiętnienia tego, co było ważne. Dzwony to swoiste pomniki, które dźwiękiem przekazują

27 Szydłowski 1922, s. 1.

${ }^{28}$ Szydłowski 1922, s. 1.

${ }^{29}$ W 1944 roku w czasie przechodzenia frontu przez Dobrą, została zniszczona największa, główna bania nad nawą cerkwi pw. św. Mikołaja, a w niej przestrzelono dzwon. Dzwon został zdjęty i ukryty przez mieszkańców. W czasie prowadzenia badań terenowych, w ramach projektu pt. Dzwony w pejzażu pogranicza nadsańskiego udało się wydobyć dzwon z ukrycia. Dzwon jest odlany z brązu, na szyi widnieje napis: „Roku 1631 m(iesią)ca maja dnia 30” w języku ukraińskim, a pod nim ozdobny ornament. 


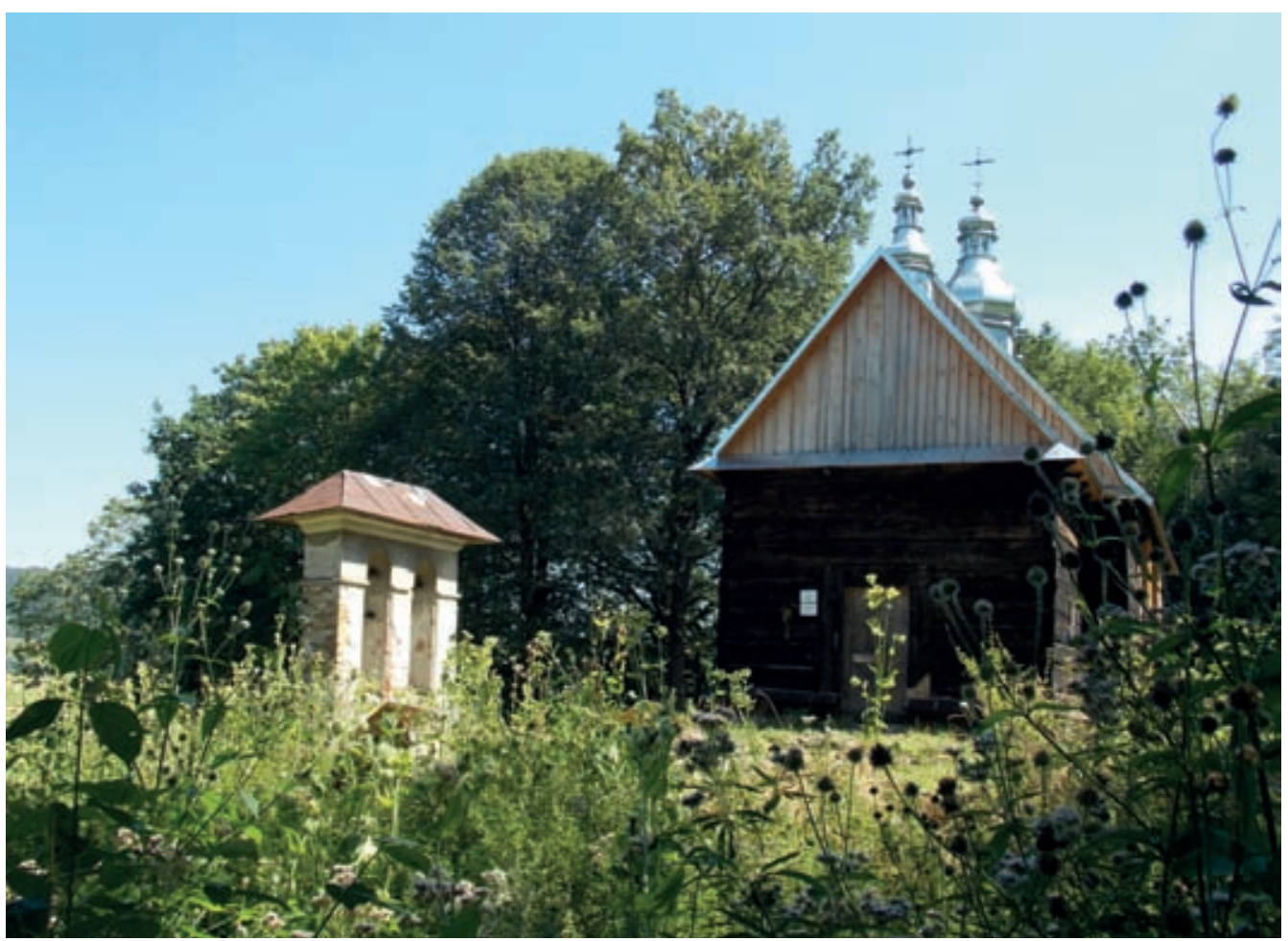

Fot. 5. Dawna cerkiew greckokatolicka p.w. św. Szymona Słupnika, Chyrzyna, gm. Krzywcza, fot. P. Karnas 2017

chwałę bohaterów i doniosłość wielkich czynów lokalnych i narodowych, są symbolem świętości, trwałości i potęgi. O dzwonie tak pisze Sebastian Bernat: „Przez wieki miał coś do przekazania ludziom, przyciagał i jednoczył społeczność i wydaje się, że obecnie mimo prób nie został on zastąpiony niczym innym”30. Dźwięk dzwonu jest nadal nośnikiem pamięci, ale także ich materialna forma jest wykorzystywana do utrwalenia ważnych wydarzeń.

Nostalgia za dawnymi czasami szczególnie uwidacznia się we wspomnieniach związanych z zimą, kuligami i przejażdżkami saniami. Niemal wszyscy respondenci wspominają o przyjemnym dźwięku dzwoneczków w czasie zimowej sanny. Dla mieszkanki Babic bardzo żywy był taki obraz:

Oj, pamiętam te czasy, kiedy w zimie się saniami jeździto, a konie miaty dzwoneczki i tak się ten dżwięk rozlegat. Teraz to konia na wsi się nie uświadczy. A te konie z dzwonkami to nadawaty wsi takiego uroku. Można powiedzieć, że ten dźwięk byt charakterystyczny dla dawnej zimowej wsi [K., ur. 1947 r., Babice, gm. Krzywcza].

\footnotetext{
${ }^{30}$ Bernat 2011, s. 194.
} 
W różnych nostalgicznych obrazach związanych z dzwonami ujawnia się idea domowości i zamieszkiwania. Przywołuje dawne czasy i wydarzenia, w których ludzie czuli się dobrze i swojsko. Kluczowy dla rozważań o retrotopii jest wiek respondentów. Osoby z dużym bagażem doświadczeń życiowych chętnie wracały do czasów swojej młodości, do opowieści ludzi im bliskich (mama mi mówita; pamiętam, jak babcia opowiadata itp.). Wspomnienia o tym, jak dawniej postrzegane były dzwony stają się „podwaliną" zadomowienia.

\section{Bezpieczne zamieszkiwanie}

Przestrzeń zadomowienia gwarantuje bezpieczeństwo i uwolnienie od lęków. Ochronę i spokój mogą zapewniać zarówno realne działania i środki, jak też różnego rodzaju apotropeiony. Dzwony i wydobywany z nich dźwięk były sposobem ochrony, informacji i wpływania na rzeczywistość, ponieważ były głosem Boga, ale też wierzono w ich magiczne wibracje i opiekuńczość. Te odlane ze spiżu lub brązu instrumenty pełniły przez wieki wiele funkcji, które gwarantowały bezpieczeństwo przestrzeni. Zebrany materiał badawczy dotyczy pamięci, o tym, jak dzwony były wykorzystywane do zapewnienia bezpiecznego zamieszkiwania. Dziś mieszkańcy pogranicza nadsańskiego nie łączą apotropeicznych właściwości dzwonów z codziennym życiem, ale jeszcze pamiętają o takiej roli tego kościelnego instrumentu.

Bezpieczne zamieszkiwanie wynika $z$ wiedzy człowieka o otaczającej go przestrzeni. Dźwięk dzwonu był czytelnym znakiem wydarzeń, które dotyczyły społeczności lokalnej. Był sygnałem informacyjnym, o czym mówił mieszkaniec Tyrawy Solnej:

Dzwon taki, takie ostrzeżenie, byt, pamiętam, pamiętam tam koto świetlicy, taki specjalny dzwon, duży. Dzwonili, jak zebranie robili lub trzeba byto zebrać ludzi. W 1939 roku jak wojna powstata to tė̇ tym dzwonem dzwonili [M., ur. 1930 r., Tyrawa Solna, gm. Sanok].

Odlany z brązu instrument kościelny pełnił przez lata rolę zegara i bił w określonych porach. Gdy pojawiał się jego dźwięk w innym czasie, przynosił niepokój, a nawet poczucie zagrożenia. Muzyka dzwonu wyznaczała rytm dnia, o którym obecnie nadal się pamięta na pograniczu nadsańskim:

Dzwoni to się trzy razy, rano, jak dzień powstaje, to żeby wstawać, w potudnie i pod wieczór. Dawni ludzie, jak byli w polu, to styszeli w potudnie dzwon z cerkwi i wiedzieli, która godzina, $\dot{z}$ już czas wracaí do domu, że będzie obiad [M., ur. 1930 r., Hłomcza, gm. Sanok].

Jeszcze dziś zdarza się, że na dźwięk południowych dzwonów ktoś zatrzyma się, przerwie pracę i odmówi modlitwę Anioł Pański. Taka reakcja na dźwięk kościelnych dzwonów dotyczy przede wszystkich ludzi starszych. 
Współcześnie zanikła informacyjna funkcja dzwonów, ale nadal mieszkańcy badanego terenu pamiętają tzw. „dzwon na trwogę”, który pojawiał się w przypadku pożaru, powodzi, huraganu lub innego niebezpieczeństwa. Mieszkanka Nozdrzca wspomina:

Ja nie pamiętam, ale opowiadali starzy ludzie, że jak się we wsi palito, to ktoś leciat do kościota, krzyczat przez wieś „alarm” i dzwonit. Potem to już byta straż pożarna [K., ur. 1946 r., Nozdrzec].

Podobnymi spostrzeżeniami dzielił się respondent z Siedlisk:

Wrazie pożaru to byty używane do tego dzwony kościelne. Jak sie gdzieś palito, a tu jeszcze straży nie byto, syreny nie byto, tylko byty używane dzwony, by powiadamiać ludzi. Pożary dawni to dla ludzi byty straszno tragedio, to trza byto powiadamiac, żeby ratować. Nie byto tak jak teraz telefonów, to dzwony dzwonity i zwtaszcza w nocy ludzi budzity, i ostrzegaty, $i$ zwotywaty na ratunek [M., ur. 1929 r., Siedliska, gm. Nozdrzec].

Z kolei w Krzywczy dzwoniono, gdy wieś była zagrożona napadem band ukraińskich: Jak banderowcy palili tu za Sanem, to ktoś dzwonit, żeby ludzie sie chowali [K., ur. 1926 r., Krzywcza]. Dzwony informowały też o radosnych wydarzeniach, na przykład o nowym roku. W czasie badań odnotowano jedną taką informację: Stychać dzwon też w Sylwestra o pótnocy. Na Sylwestra dzwonia chtopcy, że to już Nowy Rok, ale z roku na rok to już coraz mniej tego dzwonienia [M., ur. 1946 r., Brylińce, gm. Krasiczyn].

Poczucie zadomowienia i bezpieczny azyl wyznaczały granice słyszalności dzwonu. Według Robera Losiaka:

Obecność dźwięków dzwonów, górująca nad otoczeniem, rozprzestrzeniająca się na wszystkie strony świata, okazuje się głęboko zakorzeniona w przestrzeni. Dźwięk dzwonów symbolicznie wytycza granice przestrzeni, stanowi foniczne otoczenie miejsca, wyznacza swoisty „słuchokrą̧”, który określa miejsce bezpieczne, oswojone ${ }^{31}$.

Obszar pozbawiony głosu dzwonów był niebezpieczny, nieczysty, przejmujący grozą. Muzyka dzwonów wyznaczała „święty krąg”, przez który nie mogą się wedrzeć złe moce i żywioły.

Bicie dzwonów pojawiało się na granicy życia i śmierci. W tradycji lokalnej wielu miejscowości pogranicza nadsańskiego nadal funkcjonuje dźwięk dzwonów śmierci.

Jak ktoś umrze, to daja znaí do księdza i dzwony dzwoniq. Jak leży nieboszczyk, to i dzwony dzwoniq. Wiadomo, że to dla zmartego, bo tak normalnie, to dzwoniq jednym dzwonem,

${ }^{31}$ Losiak 2011, s. 46. 
a zmartemu bija wszystkie dzwony, to my odróżiamy, czy to takie codzienne dzwonienie, czy któs umart [K., ur. 1928 r., Wara, gm. Nozdrzec].

W dawnych czasach potężne żywioły, takie jak burze, pioruny, gradobicia stanowiły zagrożenie dla plonów, a nawet zabudowań ludzkich. Lud wiejski stosował wiele praktyk o charakterze religijno-magicznym, by ustrzec się przed groźnymi żywiołami. Do odpędzania burz używano także dzwonów i dzwonków. Gdy zbliżała się burza, dzwonnik chwytał za sznury dzwonów, a dźwięk rozkołysanego spiżu miał chronić wieś przed piorunami. Taką samą funkcję pełniły małe dzwonki loretańskie, którymi dzwoniono wokół domów i zagród, by piorun nie uderzył i wiatr nie spowodował zniszczeń. Działanie dzwonów polegało na odpędzaniu płanetników, którzy ciągnęli burzowe chmury. Dziś w płanetników na terenie pogranicza nadsańskiego nikt nie wierzy, a dzwonienie na burzę mieszkańcy traktują z przymrużeniem oka, jako nieistniejący relikt dawnych wierzeń, o czym świadczy ta wypowiedź:

Nie wiem, czy to prawda czy to fatsz, ale tak mówili, że tam w Uluczu mieli taki dzwon do odganiania burz. Nie byto wolno nikomu dzwonic, tylko bytjeden do tego $d z$ wonienia przeznaczony. Ten chtop do tego dzwonienia, to mówili, że musi byćstary kawaler, co z babom nigdy nie tego. Byto tak, że chmara szta i poszedt inny chtop zadzwonić, bo tamten byt gdzies daleko, to taka burza sie zrobita, że budynki rozwalato, byt straszny grad. Ale czy to prawda, to nie wiem. To starzy ludzie mówili o tym [M., ur. 1939 r., Witryłów, gm. Dydnia].

Jednak w jednej z podkarpackich miejscowości - Gaci koło Przeworska - ta wydałoby się nieistniejąca tradycja dzwonienia przeciw burzy jest nadal żywa. Jeden z dzwonów służy do odpędzania gradowych chmur, a mieszkańcy mocno wierzą w jego skuteczność.

\section{Zakończenie}

Dzwony mają długą i bogatą tradycję, która jak w soczewce skupia emocje, wierzenia, sentymenty i wartości społeczności lokalnej. Oddziałują na ludzi poprzez przypisywane im religijne i symboliczne znaczenie. Ten dźwięk przyczynia się do kształtowania wspólnoty i poczucia „bycia u siebie”. Kody kulturowe określają odbiór dźwięku dzwonów, przypisywane im wartości i sensy.

Muzyka dzwonów podkreśla koloryt miejsca i jego akustyczną wyjątkowość. Bicie dzwonów towarzyszy lokalnym wspólnotom w dni świąteczne i zwykłe. Dźwięk ten stanowi stały punkt zakotwiczający, co daje poczucie zadomowienia i zakorzenienia. Instrumenty te budują poczucie stabilności w przestrzeni zamieszkiwania.

Wyniki badań przeprowadzonych na terenie pogranicza nadsańskiego pokazują, że większość respondentów łączy dzwony z bogatą warstwą wierzeniową i tradycją przodków. Muzyka dzwonów staje się jednym z fundamentów poczucia swojskości. Wyraźnie 
uwidaczniają się pozytywne emocje związane $\mathrm{z}$ dzwonami. W badaniach na terenie pogranicza nadsańskiego nie stwierdzono negatywnych wypowiedzi o hałaśliwości dzwonów.

\section{Bibliografia}

Bauman Z. 2011, Ponowoczesne typy osobowości, „Studia Socjologiczne”, nr 1, s. 435-458.

Bauman Z. 2018, Retropia. Jak rządzi nami przesztośc, Wydawnictwo Naukowe PWN, Warszawa. Bernat S. 2011, Krajobraz dżwiękowy jutra, [w:] Bernat S. (red.), Niematerialne wartości krajobrazów kulturowych, Prace Komisji Krajobrazu Kulturowego Polskiego Towarzystwa Geograficznego nr 15, Sosnowiec, s. 193-205.

Borawski A. 1921, O ludwisarstwie i dzwonach w Polsce, „Przemysł i Rzemiosło. Czasopismo poświęcone wytwórczości przemysłowej i rękodzielniczej oraz sztuce plastycznej”, Organ Miejskiego Muzeum Przemysłowego im. Dra Adrjana Baranickiego w Krakowie, nr 1, 49-56.

Ciechorska-Kulesza K. 2018, Odczarowane blokowiska? Rola i przykłady kotwic tożsamościowych w wybranych gdañskich dzielnicach, [w:] Łukasiuk M., Brosz M. (red.) Zadomowienie. Konteksty empiryczne, Wydawnictwo Zakładu Realizacji Badań Społecznych Q\&Q, Kawle Dolne, s. 86-100, https://depot.ceon.p1/handle/123456789/16313, 05.01.2019.

Corbin A. 1998, Village Bells: Sound and Meaning in the Nineteenth - Century French Countryside, Columbia University Press, New York.

Dziura M. 2017, Dzwon w pejzażu pogranicza nadsańskiego, Muzeum Narodowe Ziemi Przemyskiej, Przemyśl.

Grzymała-Kozłowska A. 2013, Zarys koncepcji spotecznego zakotwiczenia inne spojrzenie na tożsamośc, adaptację i integrację imigrantóww, „Kultura i Społeczeństwo”, nr 3, s. 45-60.

Komorowski W. 1988, Historia dzwonów. Zabytkowe dzwony karpackie, Wydawnictwo SKPB, Warszawa.

Losiak R. 2010, O opisach pejzaży dżwiękowych, [w:] Łukaszewicz K. (red.), Nowy idiografizm?, „Prace Kulturoznawcze” t. XI, Wrocław, s. 224-232.

Losiak R. 2011, Recepcja dźwięków świątyń we wspótczesnym krajobrazie fonicznym miast, [w:] Bernat S. (red.), Niematerialne wartości krajobrazów kulturowych, Prace Komisji Krajobrazu Kulturowego Polskiego Towarzystwa Geograficznego nr 15, Sosnowiec, s. 38-53.

Losiak R. 2012, Pamięć przywotana. W poszukiwaniu mnemotopów fonicznych, „Przegląd Kulturoznawczy", nr 2, s. 141-152.

Losiak R., Tańczuk R. 2015, Pejzaż dźwiękowy miejsca zamieszkania w doświadczeniu wrocławian, „Studia Etnologiczne i Antropologiczne”, nr 1, s. 191-203.

Łukasiuk M. 2018, Czy(m) jest zadomowienie, [w:] Łukasiuk M., Brosz M. (red.), Zadomowienie. Konteksty empiryczne, Wydawnictwo Zakładu Realizacji Badań Społecznych Q\&Q, Kawle Dolne, s. 6-14, https://depot.ceon.pl/handle/123456789/16313, 05.01.2019. 
Majer A. 2011, Lokalnośc w cieniu globalizacji, „Annales Universitatis Mariae Curie-Skłodowska”, Lublin-Polonia, Vol. XXXVI, 2, sectio 1, s. 27-46.

Murray Schafer R. 1982, Muzyka środowiska, „Res Facta”, nr 9, s. 288-315.

Murray Schafer R. 1994, The Soundscape: Our Sonic Environment and the Tuning of the World, Vt: Destiny Books, Rochester.

Szydłowski T. 1922, Z dziejów odlewnictwa w Polsce, [w:] Szydłowski T. (red.) Dzwony starodawne, Drukarnia Uniwersytetu Jagiellońskiego, Kraków.

Tańczuk R. 2015, „Pejzaż dźwiękowy” jako kategoria badań nad doświadczeniem miasta, [w:] „Audiosfera. Koncepcje - badania - praktyki”, nr 1, s. 10-19.

Tönnies, F. 2008, Wspólnota i stowarzyszenie, Wydawnictwo Naukowe PWN, Warszawa. 